\title{
QUALITY
}

Volume 6, Nomor 1, 2018: 31 - 39

\section{KAITAN MANAJEMEN PENDIDIKAN TERHADAP PENGUATAN KARAKTER SISWA DI MI RUHUL QUR'AN PANCUR}

\author{
Lia Nur Khamidah \\ IAIN Kudus, Kudus, Indonesia \\ lianurkhamidah89@gmail.com \\ Arghob Khofya Haqiqi \\ IAIN Kudus, Kudus, Indonesia \\ arghobhaqiqi@stainkudus.ac.id
}

\begin{abstract}
Abstrak
Tujuan dari penelitian ini adalah untuk mengetahui dan mendiskripsikan kaitan manajemen pendidikan terhadap penguatan karakter siswa yang berada di Madrasah Ibtidaiyah (MI) Ruhul Qur'an Pancur Kabupaten Jepara. Metode penelitian yang digunakan yaitu metode penelitian kualitatif deskriptif dengan teknik observasi, wawancara, dan dokumentasi. Manajemen merupakan induk dari sebuah kegiatan yang mempunyai definisi yang bervariasi, dalam mengemukakan manajemen sebagai mengelola orang-orang, mengambil keputusan, proses mengorganisasi dan memakai sumber-sumber untuk menyelesaikan tujuan yang sudah ditentukan. Manajemen yang baik ialah manajemen yang tidak jauh menyimpang dari konsep, dan yang sesuai dengan obyek yang ditanganinya serta tempat organisasi itu berada Hasil penelitian menunjukkan bahwa di Madrasah Ibtidaiyah Ruhul Qur'an Kabupaten Jepara terdapat berbagai macam pengembangan mutu manajemen pendidikan meliputi kegiatan Jumat beramal, di mana kegiatan ini untuk menanamkan karakter, kepribadian, sifat keikhlsan,tolong menolong dan kesetiakawanan. Kemudian juga menjaga kebersihan lingkungan yang biasa disebut Sabtu bersih, kegiatan ini mengajarkan siswa supaya bisa menjaga kesehatan diri sendiri serta lingkungan baik di sekolah maupun di rumah.
\end{abstract}

Kata Kunci: Manajemen Pendidikan, Penguatan Karakter Siswa

\begin{abstract}
The purpose of this study is to find out and describe the relationship of educational management to the strengthening of the character of students who are in the Madrasah Ibtidaiyah (MI) Ruhul Qur'an Pancur Jepara Regency. The research method used is descriptive qualitative research methods with observation, interviews, and documentation techniques. Management is the parent of an activity that has various definitions, in expressing management as managing people, making decisions, the process of organizing and using resources to complete predetermined goals. Good management is management that is not far from the concept, and in accordance with the object being handled and where the organization is located. The results of the study show that in Madrasah Ibtidaiyah Ruhul Qur'an, Jepara Regency, there are various kinds of quality development development in education management, including the activities of Friday charity, in where this activity is to instill character, personality, sincerity, please help and solidarity. Then also maintain the cleanliness of the environment which is usually called Saturday clean, this activity teaches students to be able to maintain their own health and the environment both at school and at home
\end{abstract}

Keywords: Education Management, Strengthening Student Character 


\section{A. Pendahuluan}

Manajemen merupakan induk dari sebuah kegiatan yang mempunyai definisi yang bervariasi, dalam mengemukakan manajemen sebagai mengelola orang-orang, mengambil keputusan, proses mengorganisasi dan memakai sumber-sumber untuk menyelesaikan tujuan yang sudah ditentukan. Manajemen yang baik ialah manajemen yang tidak jauh menyimpang dari konsep, dan yang sesuai dengan obyek yang ditanganinya serta tempat organisasi itu berada. Sebagai bagian dari suatu ilmu, seharusnya manajemen itu tidak boleh menyimpang dari konsep manajemen yang sudah ada. Namun variasi bisa terjadi akibat kreasi dan inovasi para manajer. Variasi ini berkaitan dengan obyek yang ditangani dan tempat organisasi itu. Artinya setiap obyek membutuhkan cara tersendiri untuk menanganinya, begitu pula masing-masing tempat organisasi memiliki situasi dan kondisi yang berbeda yang membutuhkan penyesuaian pula bagi manajemen pada organisasi itu. Itulah sebabnya variasi-variasi seperti itu wajar ada dan bisa diterima. Dale (2011: 7)

Manajemen yang dapat menyesuaikan diri dengan berbagai situasi dan kondisi disebut manajemen yang fleksibel.banyak para ahli yang merumuskan beberapa fungsi. Fungsi manajemen merupakan landasan atau elemen dasar yang dijadikan rujukan atau acuan untuk melakukan berbagai kegiatan manajemen dalam suatu organisasi. (Pidarta, 2011: 19).

Pendidikan karakter mempunyaia arti sebagai suatu proses pendidikan yang berlangsung di mana saja, baik dalam situasi pendidikan formal, nonformal maupun informal dalam keluarga maupun masyarakat. Pendidikan karakter ialah proses yang secara sistematis disusun dan dilaksanakan di dalam suatu satuan pendidikan melalui proses yang sengaja diciptakan maupun proses yang berlangsung secara nyata walaupun tidak disengaja, tetapi berpengaruh terhadap internalisasi suatu nilai karakter menurut (Suryadi, 2014: 104).

Pendidikan karakter yang dilakukan dalam bentuk kegiatan tesebut disatukan dalam proses pembelajaran di MI Ruhul Qur'an, sebagai pembangunan karakter siswa yang diantaranya seperti, penilaian pembelajaran yang mengacu kepada karakter siswa dimana acuan penilaian adalah sikap dan perilaku siswa selama proses pembelajaran dikelas meskipun siswa kurang dapat memahami 
pelajaraan namun memiliki sikap dan perilaku yang baik selama proses pembelajaran, maka hal tersebut menjadi pertimbangan dalam memberikan nilai.

Tujuan pendidikan karakter rmerupakan penenaman nilai dalam diri siswa dan pembaruan tata kehidupan bersama yang lebih menghargai kebebasan individu. Tujuan jangka panjangnya tidak lain adalah mendasarkan diri pada tanggapan aktif kontekstual individu atas impuls natural sosial yang diterimanya, yang pada gilirannya semakin mempertajam visi hidup yang akan diraih lewat proses pembentukan diri secara terus menerus (Asmani, 2013).

\section{B. Pembahasan}

Jenis penelitian ini merupakan penelitian kualiatatif deskriptif, yaitu penelitian yang bermaksud untuk memahami fenomena tentang apa yang dialami oleh subjek penelitian secara holistik dan dengan cara deskripsi dalam bentuk katakata dan bahasa, pada suatu konteks khusus yang alamiah (Barnawi, 2016). Peneliti adalah sebagai instrumen kunci, pengambilan informasi kunci dan informan pendukung, tehnik pengumpulan dengan trianggulasi (gabungan), analisis data bersifat induktif/kualitatif, dan hasil penelitian kualitatif lebih menekankan makna dari pada generalisasi (Arikunto, 2010) Tempat penelitian adalah di Madrasah Ibtidaiyah Ruhul Qur'an Pancur yaitu sebuah unit pelaksana teknis pendidikan (sekolah) yang terletak di Desa Pancur, Kecamatan Mayong, Kabupaten Jepara. Penelitian ini dilakukan pada tahun akademik 2018/2019. Tahap-tahap penelitian ini dilakukan sebagai berikut:

1. Tahap konseptual

2. Perancangan dan perencanaan.

3. Mendesain instrumen pengumpulan data penelitian.

4. Fase empirik

5. Fase analitik, yakni pengolahan dan penganalisisan data hasil penelitian untuk memperoleh simpulan

6. Fase desiminasi, yakni penyusunan laporan penelitian untuk memperoleh simpulan.

Prosedur pengumpulan data yang dimaksud adalah cara untuk memperoleh data yang diperlukan di lapangan, adapun prosedur pengumpulan data yang dilakukan melalui metode observasi, wawancara, dan dokumentasi. Teknik yang 
digunakan untuk mengumpulkan data meliputi observasi,wawancara dan kajian dokumen.

Berdasarkan penelitian yang telah dilaksanakan didapatkan bahwa pendidikan karakter memang harus ditanamkan sedini mungkin pada anak. Proses pemahaman pendidikan karakter paling baik adalah pada usia 5-11 tahun. Di usia ini, anak cenderung masih memiliki sifat patuh dan juga sedang dalam proses meniru keteladanan dari orang lain. Pendidikan karakter di madrasah dan orang tua harus bersama-sama memanfaatkan momen ini untuk menanamkan pendidikan karakter yang baik pada anak sebagai dasar untuk menentukan pribadi anak itu sendiri di masa mendatang. Pada saat siswa datang pagi hari ke Madrasah guru piket terdiri dari tiga orang sudah berdiri di depan pintu masuk gerbang MI Ruhul Qur'an Pancuruntuk menyambut kedatangan siswa dengan cara berjabat tangan. Kegiatan ini dilaksanakan secara rutin setiap hari dengan dijadwal semua guru, baik guru senior maupun guru yang masih baru, kegiatan berjabat tangan pada pagi hari ini sebagaimana temuan lapangan bahwa: Pendidikan karakter di MI Ruhul Qur'an PancurKabupaten Jeparaini dilaksanakan berbagai aktifitas seperti berjabat tangan pagi hari, kemudian diawali dengan sholat dhuha bersama dan di lanjutkan dengan membaca asmaul khusna. Setelah itunsebelum pelajaran di mulai di biasakan denan menghafal surat-surat pendek dengan pembiasan-pembiasaan ini diharapkan siswa akan terbiasa dan terus melakukannya meskipun tidak di lingkungan madrasah.

Membaca Asmaul Husna yang dilakukan di Madrasah Ibtidaiyah Ruhul Qur'an Pancur Jepara merupakan salah satu bentuk implementasi dari pendidikan karakter,sholat dhuha dan pembacaan Asmaul Husna pada pagi hari dimaksudkan agar siswa terbiasa mengamalkan dan menghafal Asmaul Husna dan istiqomah dalam melaksanakan nya karena dalam ajaran Islam barang siapa menjelaskan bacaan Asmaul Husna merupakan treatmen hati menuju kepada pembentukan sikap dan karakter serta akhlakul kharimah.serta khikmah dari sholat dhuha agar selalu mendapatkan rizki yang halal dan tiada terputus.Sholat dhuha dan Pembacaan Asmaul Husna sebagaimana temuan di lapangan dari hasil wawancara maupun observasi bahwa:siswa pada pagi hari hasil pengamatan lapangan sholat dzhuha dan membaca Asmaul Husna secara bersama-sama serta berdoa pada saat akan dimulai pelajaran di kelas, sedangkan guru ikut memandu jalannya pembacaan Asmaul Husna, nampak pula guru mengkondisikan sebagian siswa yang tidak ikut sholat dzuha dan membaca Asmaul Husna yang dilakukan di mushola MI Ruhul Qur'an 
Dalam pendidikan karakter di Madrasah, semua komponen (stakeholders) harus dilibatkan, termasuk komponen-komponen pendidikan itu sendiri, yaitu isi kurikulum, proses pembelajaran dan penilaian, kualitas hubungan, penanganan atau pengelolaan mata pelajaran, pengelolaan sekolah, pelaksanaan aktivitas atau kegiatan ko-kurikuker, pemberdayaan sarana prsarana, pembiayaan, dan etos kerja seluruh warga dilingkungan madrasah. Kegitan yang rutin dilaksanakan dalam rangka menanamkan kepribadian yang baik kepada anak adalah berdoa, kegiatan berdoa bersama dimaksudkan untuk mendoakan pembelajaran di pagi hari agar lancar dan tidak halangan serta berdoa pada jam pulang adalah agar semua siswa selamat sampai di rumah, kegiatan berdoa ini dimaksudkan untuk menanamkan kebiasaan anak berdoa kepada Allah SWT. Kegiatan berdoa ini sebagaimana hasil temuan lapangan "Pendidikan Karakter di Madrasah Ibtidaiyah Ruhul Qur'an Pancur Kabupaten Jepara ini dilaksanakan dengan berbagai fasilitas seperti berjabat tangan pagi hari,sholat dzuha berjamaaah membaca Asmaul Husna maupun berdoa saat memulai pelajaran di kelas dengan pembiasaan-pembiasaan diharapkan siswa akan terbiasa dan terus melakukannya meskipun tidak di lingkungan sekolah.

Berjamaah sholat dhuhur sebagaimana temuan lapangan adalah salah satu upaya madrasah menanamkan nilai-nilai karakter siswa, melalui pembiasaan dalam kegiatan sholat dhuhur berjamaah siswa akan lebih tekun dan disiplin beribadah kepada Allah SWT, kegiatan beribadah ini sesuai dengan hasiltemuan lapangan bahwa kegiatan-kegiatan keagamaan siswa seperti sholat dzuha dan membaca Asmaul Husna yang dibaca pada pagi hari oleh semua siswa yang dipandu oleh salah satu guru, kemudian shalat dhuhur secara berjamaah, karena madrasah ini sudah memiliki mushola sendiri jadi ada program berjamaah yang dikomando oleh salah satu guru.

Shalat berjamaah sebagai bagian dari implementasi pendidikan karakter juga sesuai teori tujuan pendidikan nasional (2007) bahwa tujuan pendidikan adalah untuk berkembangnya potensi peserta didik agar menjadi manusia yang beriman dan bertaqwa kepada Tuhan Yang Maha Esa, berakhlaq mulia, sehat, berilmu, cakap, kreatif, mandiri, menjadi warga negara yang demokratis, dan bertanggung jawab. Tujuan akhir dari pendidikan karakter adalah bagaimana manusia dapat perilaku sesuai dengan kaidah-kaidah moral. Menurut Berman, iklim sekolah yang kondusif dan keterlibatan kepala sekolah dan para guru adalah faktor penentu dar iukuran keberhasilan interfensi pendidikan karakter di sekolah. Dukungan sarana 
dan prasarana sekolah, hubungan antar siswa, serta tingkat kesadaran kepala sekolah dan guru turut menyumbang bagi keberhasilan pendidikan karakter ini, di samping kemampuan diri sendiri melalui motivasi, kreatifitas dan kepemimpinannya yang mampu menyampaikan konsep karakter pada anak didiknya dengan baik. Di lingkungan desa Pancur menjadi salah satu pendukung terlaksananya pendidikan karakter di Madrasah Ibtidaiyah Ruhul Qur'an Kabupaten Jepara sebagaimana temuan lapangan bahwa "Tentu masyrakat dan orang tua sangat mendukung adanya pendidikan karakter di Madrasah Ibtidaiyah Ruhul Qur'an Pancur Kabupaten Jepara, karena masyarakat Pancur termasuk masyarakat yang agamis,justru lingkungan inilah yang menjadi salah satu suksesnya pendidikan karakter di sini”.

Lingkungan masyarakat yang agamis di desa Pancur menjadi salah satu pemicu keberhasilan pendidikan karakter di Madrasah Ibtidaiyah Ruhul Qur'an Kabupaten Jepara,lingkungan yang agamis secara tidak langsung ikut mendidik anak-anak mengenal lebih dekat dengan nilai-nilai agama Islam,dan tidak terpengaruh dengan kondisi lingkungan yang tidak baik, adanya lingkungan masyarakat yang agamis adalah sebagai mana wawancara bahwa "Lingkungan masyarakat Pancur masih kental sengan keagamaan sehingga cocok jika di Madrasah Ibtidaiyah Ruhul Qur'an Pancur Kabupaten Jepara melaksanakan pendidikan karakter, sehingga ada keterpaduan antara lingkungan yang sudah agamis kemudian didukung penanaman karakter yang baik di madrasah sehingga membentuk siswa yang berakhlakul karimah.

Dukungan aktif dari komite sekolah diantaranya berupa pertimbangan, pemikiran maupun pengawasan dari pelaksanaan pendidikan karakter, peran komite sekolah dalam pelaksanaan pendidikan karakter ini mendapat apresiasi dari semua dewan guru maupun kepala sekolah, peran komite dalam mendukung implementasi pendidikan karakter sebagaimana hasil temuan lapangan bahwa komite sekolah aktif memberikan masukan dan pertimbangan. Dukungan komite dalam pelaksanaan pendidikan karakter di Madrasah Ibtidaiyah Ruhul Qur'an Pancur Kabupaten Jepara sesuai dengan teori dari dalam. Pendidikan non formal yaitu pendidikan madrasah diniyah pada sore hari ikut menjadi salah satu faktor pendukung adanya implementasi pendidikan karakter di Madrasah Ibtidaiyah Ruhul Qur'an Pancur Kabupaten Jepara. Faktor pendukung yaitu Madrasah Diniyah sebagaimana hasil temuan lapangan tampak dalam pengamatan anak setelah pulang sekolah kemudian pukul 14.00-16.00 masuk Madrasah Diniyah. 
Pembelajaran yang dilaksanakan juga selaras dengan pendidikan karakter di Madrasah Ibtidaiyah Ruhul Qur'an Pancur Kabupaten Jepara pada pagi hari, pada Madrasah Diniyah siswa masuk kelas kemudian guru juga masuk kelas dan kemudian siswa berjabat tangan dengan guru, kemudian juga membaca doa sebelum dimulai pelajaran, dan semua mata pelajaran yang diajarkan adalah pelajaran berbasis agama, dan siswanya memakai busana muslim. Belajar Alqur'an setelah magrib menjadi salah satu prioritas pendidikan non formal yang ikut membantu terlaksananya pendidikan karakter di Madrasah Ibtidaiyah Ruhul Qur'an Pancur Kabupaten Jeapara sebagaiman temuan lapangan bahwa "Orang tua terutama ibu sangat memperhatikan sikap dan perilaku anaknya di rumah, anaknya selalu ditanya tentang perkembangan belajar, dan disuruh untuk selalu sholat berjamaah, disamping itu di malam hari ditanya untuk selalu ikut mengaji Al-Qur'an di mushola bersama ustadz, dan malam hari setelah isyak belajar pelajaran Madrasah Ibtidaiyah".

Dasar pengembangan pendidikan karakter di madrasah mengacu pada UU Nomor 20 Tahun 2003 Tentang Sistem Pendidikan Nasional (SPN). Dalam pasal 3 disebutkan fungsi dan tujuan pendidikan nasional dalam membentuk sumberdaya manusia berkualitas. Sejak beberapa tahun belakangan, pendidikan karakter telah diintegrasikan ke dalam kurikulum di sekolah. Hal ini mengingat pentingnya pendidikan karakter dalam membentuk karakter siswa. Kegiatan ekstrakurikuler pramuka adalah kegiatan untuk menanamkan karakter, kepribadian, sifat kejujuran, kepatuhan dan kesetiakawanan. Kegiatan pramuka sebagaimana temuan lapangan hasil wawancara maupun observasi lapangan "Pengembangan pendidikan karakter di Madrasah Ibtidaiyah Ruhul Qur'an Pancur Kabupaten Jepara ini dintaranya adalah dengan mengadakan kegiatan ekstrakurikuler pramuka pada setiap hari Jumat sore. Kegiatan ekstra pramuka ini dimaksudkan untuk menanamkan sifat kedisiplinan, ketegaran, sikap patuh, serta berjiwa penolong sebagai bagian dari pengembangan pendidikan karakter siswa”. (W2/GR2/mei/2019)

Kegiatan Jumat beramal adalah kegiatan ini untuk menanamkan karakter, kepribadian, sifat ikhlas, tolong menolong dan kesetiakawanan. Kegiatan Jumat beramal sebagaimana temuan lapangan hasil wawancara maupun observasi lapangan "Pengembangan pendidikan karakter di Madrasah Ibtidaiyah Ruhul Qur'an Pancur Kabupaten Jepara ini dintaranya adalah dengan mengadakan kegiatan beramal seikhlasnya pada setiap hari Jumat. Kegiatan Jumat beramal ini 
dimaksudkan untuk menanamkan sifat kedisiplinan, tolong menolong, sikap ikhlas, serta berjiwa penolong sebagai bagian dari pengembangan pendidikan karakter siswa Kegitan menjaga kebersihan lingkungan ini mengajarkan anak u.ntuk senantiasa selalu hidup sehat serta mengamalkannya dalam kehidupan sehari-hari sehingga siswa di Madrasah Ibtidaiyah Al-Asy'ari Kuniran Kabupaten Pati dapat memiliki akhlakul karimah sebagaimana temuan lapangan dalam pengamatan ditemukan bahwa guru selalu menberikan pengertian entang pentingnya hidup sehat menjaga kebersihan lingkungan dengan baik yang kemudian mengamalkanya dalam kehidupan sehari-hari dengan mengamalkan hadits Nabi Muhammad SAW.

Serta dalam pengamatan salah satu bentuk kegiatan yang kami kembangkan untuk menanamkan karakter baik siswa adalah pada kegiatan tersebut siswa diajarkan untuk cinta kepada kebersihan diri, pakaian dan tempat tinggal atau lingkungan dan mengamalkannya dalam kehidupan sehari-hari. Prestasi yang dihasilkan siswa merupakn kebanggaan sekolah dan dapat menunjang keberhasilan sekolah. Di Madrasah Ibtidaiyah Ruhul Qur'an Pancur Kabupaten Jepara sengaja bagian dari pengembangan pendidikan karakter, dengan prestasi siswa yang membawa nama baik sekolah diharapkan siswa dapat memiliki jiwa berani dan tanggung jawab dan menjujung tinggi nama madrasah dan mengimplentasikan dalam kehidupan sehari-hari sebagai mana temuan lapangan bahwa piagam dan piala yang banyak itu adalah hasil prestasi siswa dalam berbagai lomba. Kegiatan lomba biasa dilakukan setiap tahun sekali diberi nama lomba kompetensi siswa. Jadi lomba ini benar-benar menguji kemampuan siswa.

Dari beberapa uraian di atas dapat diambil kesimpulan bahwa di Madrasah Ibtidaiyah Ruhul Qur'an Kabupaten Jepara meliputi:

1. Kegiatan Jumat beramal, di mana kegiatan ini untuk menanamkan karakter, kepribadian, sifat keikhlsan,tolong menolong dan kesetiakawanan,

2. Menjaga kebersihan lingkungan yang biasa disebut Sabtu bersih. Kegiatan ini mengajarkan siswa supaya bisa menjaga kesehatan diri sendiri serta lingkungan baik di sekolah maupun di rumah.

3. Prestasi siswa yang dihasilkan siswa Madrasah Ibtidaiyah Ruhul Qur'an Pan cur Kabupaten Jepara bisa menujukkan kepada masyarakat kalau siswa MI Ruhul Qur'an tidak kalah dengan siswa di sekolah lain sehimgga kepercayaan masyarakat lebih meningkat dan berminat menyekolahkan putranya di MI Ruhul Qur'an. 


\section{Simpulan}

berdasarkan hasil pembahasan pada penelitian ini dapat disimpulkan bahwa pendidikan karakter di MI Ruhul Qur'an diimplementasikan dengan melaksanakan kegiatan yang bernuansa keagamaan di lingkungan Madrasah secara terpadu dengan pelaksanaan pembelajaran selama siswa di sekolah baik itu di luar kelas maupun di dalam kelas. Penanaman karakter siswa dilakukan dengan berbagai bentuk kegiatan seperti sholat dzuha berjamaah dan membaca asmaul husna, sholat dhuhur berjamaah di mushola yang dipandu oleh salah satu guru.

MI Ruhul Qur'an dalam melakssanakan pendidikan karakter dengan merangkul semua komponen untuk saling bekerja sama, diantaranya adalah dukungan orarng tua, lingkungan masyarakat yang agamis, dukungan aktif Komite Madrasah dan adanya sekolah madrasah diniyah pada sore hari. Pengembangan pendidikan karakter di MI Ruhul Qur'an Pancur juga dengan pembiasaan jumat beramal dan selalu menjaga kebersihan lingkungan. Dengan pembiasaan itu diharapkan siswa terbiasa dan mau mengamalkannya dalam kehidupan sehari-hari baik disekolah maupun di rumah.

\section{DAFTAR PUSTAKA}

Arikunto, Suharsimi. 2010. Prosedur Penilaian Suatu Pendekatan Praktik. Jakarta: PT. Rineka Citra.

Asmani, Jamal Ma'mur. 2013. Buku Panduan Internalisasi Pendidikan Karakter di Sekolah. Jokjakarta. Diva Press

Barnawi. Arifin M. 2016 Strategi \& Kebijakan Pembelajaran Pendidikan Karakter. Jokjakarta.Ar-Ruzz Media

Dale, Timple. 2011. Memotivasi Pegawai, Seri Manajemen Sumber Daya Manusia. Jakarta: Elex Media Komputindo.

Moleong, Lexy J. 2011. Metodologi Penelitian Kualitatif, Edisi Revisi. Bandung: Rosdakarya Pidarta. 2011. Manajemen Pendidikan Indonesia, Jakarta: PT Asdi Mahasatya PT. Remaja Rosda Karya.

Suryadi, Ace. 2014. Pendidikan Indonesia Menuju 2025. Bandung: PT Remaja Rosdakarya 